\title{
第79回 九州病害虫研究会
}

\author{
2010年 1 月 27 日（水） \\ K K R ホテル熊本（熊本市千葉城町 3 -31）
}

\section{病 害 の 部}

\section{鹿児島県の促成ピーマン栽培でのトウガ ラシマイルドモットルウイルス弱毒株 （L3-163）の収量・品質への影響と仕立 て法による増収技術}

竹牟禮穣・西 八束・田布尾尚子 . 桑鶴紀充・神田絢美 ${ }^{1)} \cdot$ 小琚理絵 ${ }^{1)}$ ・ 津田新哉1)

(鹿児島農総合七・1) 中央農研)

トウガラシマイルドモットルウイルス（以下， $\mathrm{PMMoV})$ は，発生すると収量・品質の大幅な低下を 招き，経営に大きな影響を与える。PMMoVに対して 有効な防除法は臭化メチルによる土壌消毒であるが, 2013年には国連環境計画との締約により本剤は撤廃さ れる。そこで, 本病の防除に有効な弱毒ウイルスにつ いて検討した。弱毒ウイルスは「L3-163（中央農 研)」株，品種は「TM 鈴波」と「京鈴」を供試した。 その結果, 慣行栽培（弱毒ウイルス無接種・U 字 4 本 仕立て）と比較し, 弱毒ウイルス接種区（U 字 4 本仕 立て）は育苗期やほ場での生育に影響なかったものの, 上品果率が低下し, 上品果収量は「TM 鈴波」で $3 \%$, 「京鈴」で $12 \%$ 減少した。しかし，弱毒ウイルス接種 区の仕立て法を垂直 2 本仕立てにすることで, 慣行栽 培に対し $7 \%$ 増収したことから，仕立て法の変更によ り慣行栽培を上回る収量の確保が可能となり, 弱毒ウ イルス株「L3-163」の実用性は高いと考えられた。

\section{チェコ共和国東部の罹病カリフラワーか ら採集したカブモザイクウイルス分離株 のゲノム構造}

西山 舞 ·藤井幸子 · 大島一里

(佐賀大農)

カブモザイクウイルス（TuMV）は，主にアブラ ナ科の栽培作物や園芸作物に被害をおよぼし，世界中 の亜熱帯, 温帯地方に分布している。本ウイルスの起 源地は, 中央アジアから地中海沿岸を含めた南東ヨー
ロッパ地方と推定されているため, 本地方に位置する 国々の分離株を調査することは，ヨーロッパなどへの 拡散やウイルスの適応について新たな情報が得られる と予想される。そこで本研究では, チェコ共和国東部 のオロモウツ州の罹病カリフラワーから 4 分離株を採 集し, それらの生物学的性状を調査した結果, ヨー ロッパ地方の分離株に多くみられるBrassica（B）宿 主型に属した。また全ゲノム構造を決定し分子進化的 解析を行った結果，4分離株ともゲノム結合タンパク 質遺伝子に組換え部位を持っていた。既報の分離株と 共に分子系統解析を行った結果, ヨーロッパ分離株の 多くが属する world - B ゲノム型グループに属した。 以上から，チェコ共和国の東部から採集した分離株は, B 宿主型 world - B ゲノム型グループの TuMV 拡散に 影響を与えていると思われた。

\section{LAMP 法を用いたウリ類退緑黄化ウイル ス検出のためのサンプル調整処理の検討}

奥田 充・鍛治原寛 ${ }^{11}$

(九州沖縄農研・1) 山口農林総七)

LAMP法を用いたウリ類退緑黄化ウイルス (CCYV) の検出を簡便に行うためのサンプル処理法 の検討を行った。マイクロチューブにウイルス粒子を 物理的に吸着させる「チューブキャプチャー（TC） 法」では，吸着に用いる緩衝液として0.1M リン酸緩 衝液（pH4.5）を用いた場合，最も効率よく標的領域 が増幅された。また, 葉の組織をツマヨウジで突き刺 す「ツマヨウジ法」では, TC 法と比較して, 増幅効 率が劣るものの, 供試した全ての感染植物から CCYV を検出することが出来た。ッマヨウジを直接 LAMP 反応液中に浸した場合, 非特異増幅が見られ ることがあったが, ッマヨウジを少量の蒸留水中に浸 し, その後, LAMP 反応液を加えることで非特異増 幅を抑えることが出来た。また，CCYVを保毒した タバココナジラミを, RNA 分解酵素を失活させる市 販試薬 RNAsecure (Applied Biosystems 社) 中で磨砕 し, $60^{\circ} \mathrm{C} 10$ 分間処理した後, LAMP 法の鋳型とする ことで CCYV を検出することが出来た。黄色粘着卜 
ラップに捕捉したタバココナジラミは，捕捉14日後で も全ての個体から CCYV が検出可能であった。

\section{メロン遺伝資源を用いたウリ類退緑黄化 ウイルス抵抗性系統のスクリーニング}

\author{
奥田しおり・杉山充啓 ${ }^{1)}$ ・ \\ 坂田好輝 ${ }^{1)}$. 奥田 充 \\ （九州沖縄農研・1）野菜茶研）
}

ウリ類退緑黄化ウイルス（CCYV）は，タバココナ ジラミにより媒介されるクリニウイルスの一種であり, メロンとキュウリの葉に黄化を起こす。マクワ, ノー ネット系および海外のメロン品種等を用いた調査では, 供試した全ての品種が感染し, 発病程度に差は見られ なかった（杉山ら，2009）。今回, 野菜茶業研究所が 保有するインド，パキスタンおよびバングラデシュの メロン遺伝資源59系統を用いて, CCYV 抵抗性系統 の探索を行った。本葉 $1 \sim 2$ 枚期の苗にCCYV 感染 キュウリ上で飼育したタバココナジラミを 3 日間寄生 させた後, 殺虫し, 苗を直径 $12 \mathrm{~cm}$ のポットに移植し た。これをガラス温室内で 4 週間栽培した後, 各葉の 黄化程度を 0 (無病徴) 〜 4 (葉全体が黄化) の 5 段 階で調査した。また，コナジラミ寄生葉と最上位葉か ら RNA を抽出し，CCYV の感染を確認した。その結 果, 葉の黄化は系統により異なり, 平均発病度は, 0 〜3.57となった。このうち，2系統は，CCYV が検出 されなかった。また，9系統は，感染するものの平均 発病度が 1 以下であり, 耐病性が示唆された。

\section{チチコグサモドキに発生した白絹病（新称）}

\section{森田 昭}

2009年 8 月25日, 長崎県大村市鬼橋町の児童公園に 自生しているチチコグサモドキ(Gnaphalium pensylvanicum Willd. ) に, その一部が褐変枯死し, その部位にナタネ種子大で褐色球状菌核の形成を認め た。それらのチチコグサモドキを採集して褐変部から 菌の分離を行ったところ, 白絹病菌様の糸状菌が分離 され，この菌は著者が前にツワブキから分離した白絹 病に類似していた。この分離菌の馬鈴薯煎汁寒天培地 上での生育適温は $30^{\circ} \mathrm{C}$, 菌叢は白色から灰褐色, 主軸 菌糸幅，かすがい連結有などツワブキから分離された 白絹病菌と一致した。この分離菌はチチコグサモドキ に対してツワブキの白絹病菌と同様に病原性を示し, 再分離も可能であった。この結果から, 褐変症状のチ
チコグサモドキから分離された糸状菌は白絹病菌 (Sclerotium rolfsii Saccardo）と同定し，チチコグサ モドキ白絹病と呼称することを提唱する。

\section{細菌によるチャ葉の過敏感反応病斑の 自然発生}

富演 毅・尾松直志 ${ }^{11}$

(鹿児島曽於畑地かんがい農推・1 ${ }^{1}$ 鹿児島農 総七茶業部)

これまで演者らは, 台風襲来後に発生したチャ葉の 褐変症状が Herbaspirillum huttiense に近縁な細菌よ る過敏感反応病斑である可能性を報告している。今回, 台風襲来後に発生した病斑から分離した上記の細菌を 含む 4 種類の細菌が, チャ葉に過敏感反応病斑を引き 起こすことを報告する。2007年〜2008年の台風襲来後 に更新茶園や幼木茶園など合計 10 ほ場に発生していた チャ葉の褐変病斑から, チャ葉に高濃度注入接種24 48 時間後に接種部位を褐変させる細菌を27株分離した。 分離細菌は, 集落や細菌学的性質, 16S rRNA 遺伝子 分析から，先に報告したHerbaspirillum huttiense に 近縁な種（n=13）に加えて, Acidovorax avenae に 近縁な種 $(\mathrm{n}=10)$, Stenotrophomonas maltophilia に近縁な種 $(\mathrm{n}=3)$, Burkholderia plantarii に近縁 な種（n=1）の 4 種類に分類された。これらの細菌 のうち優先種 2 種は, チャ葉注入接種 4 時間後には, 過敏感反応に特異的な活性酸素の発生を誘導した。以 上より, 台風襲来後には, 非病原細菌もしくは宿主を 異にする病原細菌による過敏感反応病斑が自然発生す る可能性が示唆された。

\section{野外カンキツグリーニング病罹病樹にお ける新梢内の Candidatus Liberibacter asiaticus 濃度の季節的変動}
澤岻哲也・河野伸二・村山祐子・ 佐渡山安常・亀川 藍 (沖縄農研セ)

Candidatus L. asiaticus はミカンキジラミ（以下， D. c）によって伝搬されるが，5齢幼虫期に菌を獲得 吸汁した成虫で伝搬能力が高く, 虫体内の菌濃度も高 いことが報告されている（Inoue, H et al., 2009）。また D. c 幼虫は寄主植物の新梢で発育するが, 野外䍜病樹 におけるCandidatus L. siaticus の PCR 検出率は, 新 梢では季節的に変動し，硬化葉では一定して高い（澤 
岻ら，2008）。そこで，D. c 保毒虫発生に及ぼす罹病 樹の影響を明らかにするため，2006年－2008年にかけ て, 沖縄本島北部の与那および田港のカンキツ罹病樹 に扔いて, 新梢内の菌濃度を, 奥田ら（2009）の方法 に準じてリアルタイム PCR によって調査した。シー クワーサーでは 9 月 -12 月および 4 月に菌濃度が高ま り，2月-3 月に濃度が低下する傾向が認められた。 特に田港では，2007年 4 月の濃度は低いが，2008年か ら症状の進行に伴い 4 月の菌濃度の上昇が認められた。 タンカンでは, 菌濃度は $8-9$ 月に緩やかに高まる変 動傾向がみられ，5月に異常に高濃度を示すサンプル も確認された。以上の結果から, 野外カンキッ罹病樹 の新梢内の菌濃度には季節的変動があることが分かっ た。新梢内の菌濃度の変動は, 野外の D. c 保毒虫発生 に影響を及ぼす可能性がある。

\section{喜界島におけるカンキツグリーニング病 菌緊急防除の経過（3 年目）}

篠原和孝・叶 一寿 ${ }^{1)} \cdot$ 松比良邦彦 ${ }^{2)}$. 上福元彰 ${ }^{3)} \cdot$ 川島俊次 ${ }^{4)}$

(鹿児島農総七・ ${ }^{1}$ ) 喜界町・ ${ }^{2}$ 鹿児島農総七 大島 ${ }^{3)}$ 鹿児島大島支庁 $\cdot{ }^{4)}$ 鹿児島県庁）

鹿児島県喜界町では2003年12月にカンキツグリーニ ング病（以下, CG 病）の感染樹が初めて確認され, 2007年 4 月から CG 病菌の根絶を目的とした緊急防除 区域に指定された。喜界島全域を対象とした感染樹の 目視調査を年 3 回実施し, 疑似症状を示す葉を採取し て PCR 検定により感染の有無を確認している。また, 発生地点から半径 $500 \mathrm{~m}$ 範囲ではカンキッ全樹を毎回 調査し, 未確認地域では全カンキツ植栽地点の全樹を 対象に 3 年間で調查する計画で進めている。防除対策 としては発生地点から半径 $500 \mathrm{~m}$ 範囲では年 3 回チア メトキサム水溶剤による一斉防除を実施し, ミカンキ ジラミを極めて低密度に抑制している。さらに, 感染 樹が確認された場合は近接する半径 $5 \mathrm{~m}$ 範囲内のカン キツは全樹伐採した。その結果，2007年11月調査まで に合計12地点28樹の感染が確認されたが, 以降2009年 11月調查まで新たな感染樹は確認されていない。これ らのことより，喜界島では CG 病の感染リスクが低く 抑えられ根絶に近い状態になっていると考えられる。

\section{佐賀県内における施設キンカン特別栽培 の取り組みと技術対応}

\author{
井手洋一・近藤知弥・ 口木文孝・ \\ 平野稔邦 ${ }^{1)} \cdot$ 松瀬政司 \\ (佐賀果樹試・ ${ }^{1)}$ 西松浦農改普七)
}

佐賀県西部地域の JA 伊万里管内では約20戸の農家 が施設部会組織としてキンカンの特別栽培に取り組み、 実際に生産，販売を行っているが，年間に使用できる 化学農薬成分数がわずか 5 成分と厳しく, 病害虫対策 に苦慮していたことから，特別栽培に対応した防除技 術の開発に取り組んだ。著者らはハマキムシ類に対し て BT 剤が有効であることや，アザミウマを効率よく 防除するための散布時期を実証試験で示すとともに, 果実腐敗剂を使用しない防除体系を提案し, 技術導入 を行った。さらに, 特別栽培で化学農薬としてカウン トされないマシン油乳剂をハダニ対策や黒点病防除の アジュバントとして有効利用するために, 盛夏期にマ シン油乳剤を使用しても果実品質の低下や腐敗発生に 影響がないことを明らかにした。これらの成果は特別 栽培ガイドラインとして佐賀県施肥・病害虫防除・雑 草防除のてびきに掲載し，技術普及を図っている。現 在, 果梗部周囲の着色対策としての高温蒸気処理の有 効性や, 光反射資材によるアザミウマ類の侵入抑制効 果等について検討中である。

\section{種バレイショ消毒における薬剤噴霧処理 のジャガイモそうか病に対する効果}

平田憲二・小川哲治・松尾和敏・ 迎田幸博 $\cdot$ 山道弘敬 ${ }^{1)} \cdot$ 高瀬俊二 $^{2)}$

(長崎農技セ・ ${ }^{1)}$ TOMTEN Ltd. (トムテン) ・

2) 高瀬製作所)

環境に低負荷な種バレイショ消毒技術確立のため, ヨーロッパにおいて黒あざ病対象に行われている噴霧 処理のジャガイモそうか病に対する防除効果の検討を 行った。噴霧機は Agri Tech 社製の Minifec（ミニ フェック）を用い，処理量および処理時の塊茎への土 壤付着の有無が防除効果へ与える影響を調查した。供 試薬剤はオキシテトラサイクリン・ストレプトマイシ ン硫酸塩剤 40 倍を使用し, 処理量は塊茎 $100 \mathrm{~kg}$ 当たり $300 \mathrm{ml}$ と $600 \mathrm{ml}$ の 2 区を, また, 塊茎への土壤付着の 有無は塊茎表面に付着した大きな土塊を落とし土壤を 払っただけの区と水洗後乾燥させた区の 2 区を設定し た。対照区は水洗後乾燥した塊茎を供試薬椷に 10 秒間 
浸漬処理した。その結果, $300 \mathrm{ml}$ 処理は対照区よりも 効果が低かったが， $600 \mathrm{ml}$ 処理は対照区と同等以上の 高い効果が認められた。また, 塊茎への土壤付着有無 の影響は土壤付着区より水洗後乾燥区の効果が高かっ た。

\section{ショウガ根茎腐敗病に対するポット試験 による処理資材の効果の検討}

難波信行 · 寺本 健 · 松尾和敏

（長崎農技セ）

ショウガ根茎腐敗病は, 污染土潩及び污染種ショウ ガにより伝染し，いったん発病すると急速に曼延して 大きな被害をもたらすショウガ栽培における最重要土 壤病害である。根茎腐敗病の処理資材の検討は, 植付 ける塊茎サイズが大きく（100～150g)，植付けた塊 茎から次々に分げつして肥大するため戋場試験で行わ れている。戋場試験では, 各処理区の土壤が混ざらな いようにコンクリート枠や畦波で仕切る必要があるた め, 処理区の数を増やすことが難しい。そこで, ポッ 卜を用いて処理資材の防除効果の基礎試験を行うこと ができないか検討した。試験は，2008年に農林技術開 発センター内露地において $50 \mathrm{~cm} \times 25 \mathrm{~cm} \times 20 \mathrm{~cm}$ の

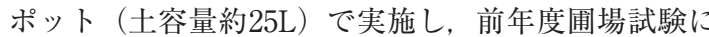
おいて防除効果を確認しているオラクル顆粒水和剤 2,000 倍液 $3 \mathrm{~L} / \mathrm{m}^{2}$ を 6 月上旬から約 2 週間間隔で 4 回, 株元中心に灌注した。その結果，ポットにおいても围 場試験と同様の防除効果が認められ，ポット試験の有 効性が確認できた。

\section{Lasiodiplodia theobromae による シュガーバイン黒枯病（新称）}

鶴屋健太・西 八束 ${ }^{1)}$. 野島秀伸 ${ }^{1)}$. 富士本晃大 ${ }^{2)} \cdot$ 中村正幸 - 岩井 久

（鹿児島大農・ ${ }^{1)}$ 鹿児島農総セ・ ${ }^{2)}$ 日野洋蘭園）

2009年, 鹿児島県薩摩郡さつま町のシュガーバイン 生産農家において, 茎の一部が黒変し, やがて株全体 が枯死する被害が発生した。病斑部から PDA 上に黒 色の菌叢を形成する糸状菌が高率に分離された。植物 体上での本菌の分生子殼は黒色で，大きさは $180 \mu \mathrm{m}$ 〜 $270 \mu \mathrm{m}$ であった。分生子は, はじめ無色，広楕円 形，単胞の未熟胞子，大きさは平均 $23.1 \times 12.15 \mu \mathrm{m}$ で，成熟胞子は，暗褐色，広楕円形で 2 胞，大きさは 平均 $23.85 \times 12.7 \mu \mathrm{m}$ であった。本菌の生育最適温度

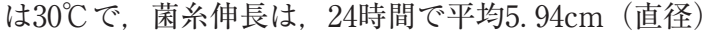
であった。本菌はバナナやビワの黒腐病およびパパイ ヤやマンゴーの軸腐病の病原菌であるLasiodiplodia theobromaeの性状とほぼ一致し，バナナ，パパイヤ， マンゴーに接種したところ病原性を示した。分離菌を 健全苗に接種したところ，同様な病徵が再現され，病 斑部からは接種菌が高率に再分離された。以上の結果 から，本菌をLasiodiplodia theobromae と同定し， シュガーバイン黒枯病と呼ぶことを提案する。

\section{イチゴ炭疽病菌の感染部位の違いが病勢 進展に及ぼす影響}

吉田満明 · 難波信行 · 寺本 健 - 松尾和敏

（長崎農技セ）

育苗期に打けるイチゴ炭疽病菌（Glomerella cingulata）の感染部位および接種菌濃度の違いが病 勢進展に及ぼす影響を検討した。炭疽病進展期の2009 年 8 月に ‘とよのか’, ‘さちのか’、 ‘こいのか’の計 3 品種を供試し，3段階（106個，104個，102個/ $\mathrm{ml}$ ）に 希釈した本病菌分生子懸濁液を小葉, 葉柄, クラウン の各部位へそれぞれ塗布接種を行い，初期病斑の形成 状況および発病株率と萎调枯死株率の推移を調查した。 その結果, 感染初期に形成された小葉の污斑状斑点数 は品種により差異が見られ，“さちのか’において最 も多く，“とよのか’および ‘こいのか’にはその半 数程度しか形成されなかった。また，発病株率の推移 は，品種による差異が見られず，感染部位に関わらず 接種27日後には，ほぼすべての供試苗が発病した。一 方, 萎调枯死株率の推移は品種および感染部位によっ て異なり，接種27日後における萎调枯死株率は, ‘さ ちのか’のクラウン部へ接種した区が最も高くなり, 次いで ‘こいのか’クラウン接種区，“さちのか’葉 柄接種区と続き，“とよのか’ 小葉接種区が最も低 かった。

\section{チアジニル粒剤を用いたイチゴ炭疽病の 育苗中における防除効果}

樋口康一・尾松直志 ${ }^{1)}$

(鹿児島農総七生産環境部・1) 鹿児島農総七茶業部)

抵抗性誘導型薬剤であるチアジニル粒剤は，これま での調査で子苗に直接処理した場合には効果は得られ ず，親株に処理した場合に効果が認められた。そこで, 親株処理後の子苗における残効について検討した。株 
あたり $5 \mathrm{~g}$ の粒剤をランナー発生初期の 4 月 22 日に親 株の株元に処理し，その後発生したランナーから採苗 した。 7 月 7 日にランナーを切り離し, 切り離し翌日 から 1 週間間隔で 4 週間後まで子苗にイチゴ炭疽病菌 を接種してその後の発病を調査した。いずれの区にお いても接種後経時的に発病株率が高まっていったが, 切り離し 3 週間後までに接種した場合, 薬剤処理区の 方が無処理に比べ発病株率が低い傾向であった。切り 離し 4 週間後に接種した場合では薬剤処理区と無処理 区に発病株率の差は認められなかった。親株への薬剤 処理によって子苗での防除効果が認められたがその効 果は 4 週間程度で消失してしまうことが示唆された。 本剤はイチゴに未登録であり, 今後は登録に向けてこ のような特性を考慮した体系的な防除法を検討する必 要がある。

\section{イチゴ萎黄病に対する高設ベンチ栽培で の土壤消毒方法の検討}

石松敏樹・岡本 潤

(大分農林水産研安全)

大分方式高設ベンチ栽培に㧍けるイチゴ萎黄病対策 として，前年の罹病残渣を残したままハウスのビニル をすべて除去した状態でベンチ表面をビニルで二重に 被覆し，8月に30日間の太陽熱消毒を行う処理（以下 ベンチ陽熱処理）を主体とした土壤消毒法を検討した。 8 月 3 半旬及び 5 半旬の日照時間が平年より少なく推 移した2008年は, ベンチ陽熱処理では効果が不十分と なったが, ベンチ陽熱処理終了10日前にクロルピクリ ンくん蒸剤（錠剂）を追加処理した場合, 発病がやや 少なく推移した。一方, 8 月 $1 \sim 3$ 半旬の日照時間が 平年より少なく推移した 2009 年は, 梅雨明け後の 8 月 5 日から 9 月 3 日まで行ったベンチ陽熱処理では防除 効果が不十分であったが, 罹病残渣を除去してベンチ 陽熱処理を行った場合防除効果が高まった。また，罹 病残渣の除去に加えてクロルピクリンくん蒸剤（錠 剂）またはカーバムナトリウム塩液剂を処理した後, ベンチ陽熱処理を行うとより高い防除効果が認められ た。

\section{促成栽培イチゴ本ぽにおける生物的防除 資材を核としたうどんこ病の減化学農薬 防除体系}

\author{
石井貴明 ·浦 広幸・森田茂樹 · \\ 柳田裕紹・嶽本弘之*
}

(福岡農総試, *現：福岡県農林水産部)

促成栽培本ぽにおけるイチゴの主要病害であるうど んこ病の減化学農薬防除体系を確立するために, 化学 農薬の効率的な使用と生物的防除資材を組み込んだ防 除体系の効果を試験場内戋場にて2006年〜07年作㧍よ び07〜08年作で検討した。その結果，06年〜07年作で は，12月中旬〜 3 月初旬のバチルス・ズブチリス水和 剂ダクト内投入散布 +3 月初旬以降化学農薬を輪番散 布する区は, 試験期間中に化学農薬を輪番散布する区 と累積発病果率を元に比較すると, 防除価はほぼ同等 の77で，化学農薬の成分使用回数を $4 / 7$ (57\%) に 抑えた。また， 07年〜08年作では，ダクト内投入散布 前の生物的防除資材の使用回数を増やしたダクト内投 入散布 + 化学農薬輪番散布の区は, 化学農薬輪番散布 区と比べ防除価はやや劣ったものの十分な果実の発病 抑制効果を示し, 化学農薬の成分使用回数は, $7 / 15$ （47\%）に抑えることができた。なお，現地実証試験 でも場内試験と同様の結果が得られた。

\section{イチゴ本戋における硫黄くん煙処理を組 み込んだうどんこ病の防除体系}

\author{
稲田稔・山口純一郎 \\ (佐賀農業セ)
}

イチゴ本戋（品種：さがほのか）におけるうどんこ 病の防除対策を確立するため, 硫黄くん煙処理を組み 込んだ防除体系を検討した。2007年作の場内試験にお いて, 本病極少発生時（発病小葉率0.3\%）からのく ん煙単独の処理（大信油化工業（株）スーパースモー キー, 3時間/日の毎日）は，葉および果実の発病を抑 制し安定した効果を示した（葉の発病度 6.5 , 果実防 除価65)。一方, 少発生時（発病小葉率9.5\%）からの 処理では葉および果実の発病を十分に抑制できなかっ た（葉の発病度16.0, 果実防除価45）。これらの結果 から, 本処理は本病の極少発生時から実施することが 必要と考えられた。そこで, 08年作の場内および現地 围場において, 定植後からの薬剤体系散布により葉で の発生を極少に抑え，その後11〜 4 月に硫黄くん煙処 理を行う防除体系の効果を検討した結果，期間を通じ 
高い発病抑制効果が認められた（場内試験平均発病果 率 $2.2 \%$, 現地 $0.4 \%)$ 。また, 放飼したカブリダニ類 の定着が認められ，本防除体系は天敵利用圃場におい ても適用可能と考えられた。

\section{セジロウンカ加害イネに誘導される病害 抵抗性への hydroperoxide lyase の寄与}

佐藤 雅 $^{*} \cdot$ 五味剣二 ${ }^{1)} \cdot$ 小澤理香 $^{2)}$ ・

真田幸代・松村正哉・高林純示 ${ }^{2)}$

(九州沖縄農研・ ${ }^{1}$ ) 香川大農・ ${ }^{2}$ 京大生態 研, *現 : 横浜植防)

セジロウンカ (以下, セジロ）の加害によってイネ に誘導される病害抵抗性のメカニズムを調査した。卜 ビイロウンカ（以下，トビイロ）の加害では抵抗性の 誘導が認められないことから，七ジロまたはトビイロ の加害を受けたイネでの遺伝子発現の挙動を比較した。 その結果, セジロに加害されたイネでは, トビイロに 加害されたイネよりも多くの抵抗性関連遺伝子が発現 していた。さらに，セジロの加害は抵抗性を全身的に 誘導することから全身的に発現する抵抗性関連遺伝子 を調べたところ，hydroperoxide lyase2(OsHPL2) が セジロの加害で特異的に発現することがわかった。 HPL は $\mathrm{C}_{6}$ 揮発性物質の合成酵素であることから, イ ネ植物体の $\mathrm{C}_{6}$ 揮発性物質を定量した結果, 抗菌活性 を持つ $(\boldsymbol{E})-2-$ hexenal がセジロウンカの加害に よって増加していた。 $(E)-2$ - hexenal を培地に加え ると白葉枯病菌の生育が阻害されることや, $(E)-2$ 一 hexenal を処理したイネに白葉枯病に対する抵抗性 が誘導されることから， $(\boldsymbol{E})-2-$ hexenal の増加がセ ジロ加害イネでの病害抵抗性誘導に寄与していると考 えられた。 